\title{
Effectiveness of Environment-Based Biology Instructional Model to Improve Students' Critical Thinking skills in High School
}

\author{
Nursidin Nursidin ${ }^{1 *}$, Rusman Rusman ${ }^{2}$. Laksmi Dewi ${ }^{3}$ \\ ${ }^{1}$ Indonesia University of Education Bandung, Indonesia \\ ${ }^{2}$ Indonesia University of Education Bandung, Indonesia \\ ${ }^{3}$ Indonesia University of Education Bandung, Indonesia \\ Email:nursidin.mpd@gmail.com
}

\begin{abstract}
This study aimed to obtain the information about the effectiveness of the Environment-Based Biology InstructionalModel that improve student's critical thinking ability in high school. The research design was a pretest-posttest group. It used Quasy Experiment. The population was 223 students in the tenth grade of Asera Senior High 1 in 2019-2020. The number of the sample was 105 students. The researcher analyzed the data into descriptive analysis and inferential statistics. Hypothesis testing was a t-test and signignficany of Model on SPSS-20 program. The results showed that students' critical thinking skill of Concept of Biodiversity taught by the Environmental-Based instructional model was higher than students who taught by Conventional Instructional Model. To sum up, it showed that using the Environmentbased Instructional was more effective than the Conventional model.
\end{abstract}

Keywords: Environmental Based, Instructional Model, Critical Thinking Comprehension, Biology

\section{INTRODUCTION}

Science is one of difficult subjects. In order to make the student easily understand the material, educators focused on how to use the innovative and integrative ways. Gallagher (Liliasari, 2007) states the students meet challenges facing a new paradigm of learning science that provides them with several experiences to understand and guide them to use scientific knowledge[1]. Science instructional models are needed as an appropriate and effective model to equip every student for applying their ability to think through scientific thinking. Critical thinking is pivotal thing for students that involved as characteristic of science view. One of the benefits of students as a critical thinker is able to identify the importance of a problem and how to figure it out.

In $21^{\text {st }}$ education tend to focus on the mastering critical thinking, creativity, communication and problem solving in facing huge challenge in technologi (Badriyah 2020)[2]. It is the reason many researchers recommend critical thingking as main focus (Susetyarini \& Fauzi, 2020) [3]. Critical thinking builds another capability. It is because of criticial thinking known as the most responsible thingking (Sari et all, 2021)[4]. In fact students found have not explored the critical thinking particularly in science subject. So that critical thinking skills and scientific attitudes are among the essential skills and knowledge that should be prioritized by $21_{\mathrm{st}}-$ century students (Fitriani et all, 2020) [5].

One of the science subjects is Biology. It is a subject that complelety related to real and abstract material. To understand the abstract and large material, the students will easily to adopt the information or material in real context and correlated it to the critical thinking.

The minister of National Education of the Republic of Indonesia Number 22 of 2006 concerning Content Standard that Biology subject needs to be given to all students, starting from elementary school to equip students with the ability to think logically, analytically, systematically, critically, and creatively, as well as the ability to work together. These competencies are needed so that students can have the ability to obtain, manage, and utilize information to survive in conditions changing, uncertain, and competitive.

There is a wide range different gap in which critical thinking skill is pivotal for learning. As data obtained by 
researchers at the achievement of the 2018 national exam results, the average score obtained by all schools in North Konawe was 24.03 to 73.54 . These results explained that students could not solve the problems, especially questions in the high-order thinking category. In general, students could not correctly answer the HOT category questions related to critical thinking understanding. Jahidin (2021) states that students' Critical thinking skills can be enhanced by authentic and meaningful examples such as adding or combining Biology material from the environment into the learning process to meet students' thinking needs [6].

The Ministry of National Education (Supriatna, 2003: 5) states that the Environment model approach is a learning concept that helps the students to make a connection between the material taught in real-world and the student's environment that supports making connections between the knowledge possessed and its application in their lives as family members of the community[7]. With this concept of learning outcomes, it is more meaningful for students to learn naturally in the form of activities, work, and experiences, not just transferring from teacher to student. By using environment based model students can directly observe the real life. As states Miarsyah \& Ristanto, (2021) that "Environment is one component of life whose condition is highly dependent on human activity, so changes always occur along with the times"[8]. The change of environment, the students use the critical thinking how and why that happened. Besides, Environment has benefit for students as stated People can use the environment since it provides various benefits for students, namely it gives, experience, , knowledge, providing awareness about what people to do the environment, and knowing the importance of the environment as our life (Ichsan et al, 2019) [9].

Thus, the researcher formulates the research question as follows; (1)"Is there any difference in students' critical thinking skills before and after applying EnvironmentBased Biology instruction model and Conventional Model"? (2) Is there any effect of using environmentbased instruction model on students' critical thinking skills?

\section{LITERATURE REVIEW}

\subsection{Instructional Concept}

Seel (2017) described that learning is process to constructive of organizing available cognitive resources and moreover, it has a manner of obtained a new knowledge and even a new skills placed at and to store and even for mastering new learning information [10]. Slavin (2006) instruction is the link between what the teacher wants students to learn and students' actual learning is called instruction [11]. On the other hand, Corder (2010) states that the term learning not only refers to receiving new knowledge; however, learning also refers to developing ideas, knowledge, skill, and strengthens an argument[12]. It is related to Prayitno (2016) states that learning is a process of changing individual behavior obtained through experience, the stimulus-response process, habituation, imitation, understanding, appreciation, and activity to achieve something he wanted[13].

According to Wina Sanjaya (2011), learning is a pprocess change of behavior, the result of experience and practice. The learning process is essentially a mental activity that cannot be known concretely[14]. The process of changing to a person who is learning cannot be observed, it is only possible to witness the existence of visible behavioral symptoms. As stated by Rusman (2017) learning is one of the factors that influence and play an important role in personal formation and individual behavior[15]. Learning is an activity psychologically or physiologically. Joyce (2015) Instructional model a model of teaching is a way of building a nurturant and stimulating ecosystem within which the students learn by interacting with its components [16].

\subsection{Environment Concept}

Syarif \& Wibisana (2012) an environment is the unity of space with all objects, forces, circumstances, and living things, including humans and their behavior, which affect nature itself, the continuity of life, and the welfare of humans and other living creatures [17]. Monroe (2004) states that an environment is the integrated context of learning in which has the potential to serve as one of these comprehensive improvement strategies[18].

Besides, Gerald Lieberman and Linda Hoody (2020) state that the environment shows that students learn more effectively in an environment-based context than in a traditional context. Benefits of an environment-based program can include improved performance on standard measures of academic achievement, reduced classroom management problems, and increased enthusiasm for learning [19].

(Nugroho 2018) efforts to use the environment in learning are to make it a learning resource. According to Bucholz and Sheffler (2009), teachers can shape the classroom environment to be comfortable, increasing the students' ability to learn a lesson[20]. A conduciveness classroom environment emphasizes cooperation and openness between teachers and students. Moreover, in learning and teaching, especially science subjects, students should interact with teachers, classmates, and the surroundings. Interaction with the environment during the learning process will stimulate all the students' senses and encourage students to learn in creative and innovative ways. 


\subsection{Critical Thinking Skill}

Butterworth \& Thwaites (2013) state critical thinking comes from the word critical. This word took from the Latin word crisis. It means separating" the life of present and past problems when faced with situations that require a particular action when it requires planning that has a positive impact[21]. Bassham, et all (2011, Ambarita et all, 2020) critical thinking is the general term given to a wide range of cognitiveskills and intellectual dispositions needed to effectively identify, analyze, and evaluate arguments and truth claimns; to discover and overcome personal preconception and biases; to formulate and present convincing reason in support of conclutions; and to make reasonable, intelligent decisions about what to believe and what to do (thinking), (remembering) and comprehending)[22].

According to Reason, remembering and understanding are more passive than thinking. Thinking is a mental activity experienced by a person when faced problem or situation that must solve. Ruggiero (Johnson 2012: 187) defines thinking as any mental activity that helps formulate or solve problems, make decisions or fulfill the desire to understand; thinking is a search for answers, a search for meaning[23].

Johnson (2007) explains that thinking is an active, orderly and meaningful process that we use to understand the world [24]. A higher mental process called thinking occurs in the brain. Recalling invites past experiences into the mind and begins to form a chain of associations. The chain of association does not refer to what is actually seen, but to mental illusions.

Critical thinking skill according to Scriven and Paul (1987) is defined that understanding critical thinking is a disciplined process that is intellectually active and skilled at conceptualizing, applying, analyzing, synthesizing, and or evaluating information collected from or generated by observation, experience, reflection, reasoning, or communication, as a guide to beliefs and actions. In the form of examples, it is based on the universal intellectual scores which go beyond the parts of the subject matter, such as clarity, accuracy, precision, consistency, relevance, proof, good reasons, depth, breadth, and reasonableness. Liliasari (2011) suggests that critical thinking is to analyze the arguments and to generate each meaning and interpretation, to develop a cohesive and logical reasoning pattern, and understand the assumptions and biases that underlie each position. Finally, you can get a presentation model that is reliable, concise, and convincing[25].

Inch et al. (2006) describe the eight elements of critical thinking which are interrelated functions as follows[26]:
Question at issue is awareness to question something that is really needed. This question is an impetus for critical thinking.

Purpose is a need that is in accordance with the objectives or results to be achieved through the inquiry process for the identification of objectives.

Information is answering questions that require appropriate information, and information that is material for developing new ideas and thinking machines.

Concepts are theories, definitions, rules, and laws that direct thoughts or actions. Concepts can provide a basis for decision-making from an activity.

Assumptions are basic assumptions that do not need to be proven true. Assumptions describe the baseline (baseline) of the mind and if there is an error or misunderstanding in assuming, then the reasoning rooted in that assumption will also be wrong.

Point of view differences in one's point of view in reasoning and thinking is part of critical thinking which involves the process of interpreting and understanding something. A person's point of view starts from his life background, experiences, ways of thinking, and attitudes.

Interpretation and drawing conclusions (interpretation and inference) are interpretation that is needed to understand the data and draw conclusions. Reasoning to draw conclusions is a combination of the ability to ask questions, test investigations, and understanding activities.

Implications and consequences are the results of reasoning and thinking. It is because critical thinking is not a single identity, but a process to produce something. Critical thinking is an important ability and an indispensable skill for a person; it can help in solving problems and making appropriate and correct conclusions. But this is not something that is easy to develop without time and discipline.

\section{METHODOLOGY}

The research was carried out at Senior High School 1 Asera, North Konawe Regency in Southeast Sulawesi Province. It is conducted from June 2019 to September 2019. The population was all students at the tenth-grade class X of Science class. It consists of six classes with 223 students. The sample was two classes, they were a class experiment. It was at classes $\mathrm{X}$ Science class III with 35 students. Besides, 35 students in the tenth grade of Science 1 as control class. Samples were choosen by using the cluster random sampling technique. The research design was quasi-experimental. In this study, the type of data collection instrument used a test. The test instrument was used to measure the understanding of critical thinking skills. The test was constructed based on the results of observations to areas used as objects of the 
Environmental-based instructional model and based on a grid of questions covered in the subtopics of Biodiversity, natural and social phenomena that were observed. The test refers to indicators of critical thinking skills with 8 indicators, namely 1) Questions on problems (question at issue); 2) Objectives (purpose); 3) Information .4) Concepts; 5) Assumptions: 6) Point of view 7) Interpretation and concluding (interpretation and inference); 8) Implications and consequences.

The analysis used a T-test to know the difference between pre-test and posttest, then it was continued to find the N-Gain as the effectiveness of both Environment-Based and Conventional models. To know the category of the effect of lecturer, it used the following category are as follows:

Tabel 1.1 Score N-Gain Category

\begin{tabular}{|l|c|}
\hline \multicolumn{1}{|c|}{ Score N-Gain } & Categories \\
\hline $\mathrm{g} \geq 0.3$ & Low \\
\hline $0.3<\mathrm{g} \leq 0.07$ & Medium \\
\hline $\mathrm{g} \geq 0.3$ & High \\
\hline
\end{tabular}

\section{RESULT AND DISCUSSION}

The results of students' critical thinking before and after apply environment-based instruction and the effectiveness of using environment-based instruction model. The results of the analysis were presented as follows.

\subsection{Description of Students' Critical Thinking before and after applying Environment-Based Model.}

The results of the descriptive analysis of critical thinking understanding before and after environmentbased learning are presenting in the following table.Table 1.2

Table 1.2 Description of Students' Critical Thinking Before and After Applying Environment-Based Model.

\begin{tabular}{|l|c|c|c|}
\hline \multicolumn{1}{|c|}{ Components } & $\begin{array}{c}\text { Before } \\
\text { treatment }\end{array}$ & $\begin{array}{c}\text { After } \\
\text { Treatment }\end{array}$ & Gain \\
\hline $\begin{array}{l}\text { Minimum } \\
\text { score }\end{array}$ & 35 & 35 & 35 \\
\hline $\begin{array}{l}\text { Maximum } \\
\text { score }\end{array}$ & 18,18 & 54,55 & 0,18 \\
\hline Average & 36,80 & 72,55 & 0,57 \\
\hline $\begin{array}{l}\text { Deviation } \\
\text { standard }\end{array}$ & 10,35 & 11,24 & 0,16 \\
\hline Varians & 107,03 & 126,37 & 0,03 \\
\hline
\end{tabular}

From on the table 1.2, it could be seen that the minimum score of critical thinking understanding before environment-based instructional model is 18.18 and after learning 54.55 with a gain of 0.18 . The maximum score before learning using the Environmental model is 60.61 , after learning 90.91 with a gain score of 0.87 . The average score before learning is 36.80 , and after learning 72.55 with a gain score is 0.57 , while the standard deviation before learning using the environment model is 10.35 and after learning 11.24 with a gain of 0.16 . This description shows, the understanding of critical thinking after being taught with environment-based learning is higher than before learning using the Enviroment model. The students' critical thinking skill taught by conventional learning tends to experience differences before and after learning using the model, as presented in the following table.

Table 1.3 Description of Students' Critical Thinking Skill Before and After Applying Conventional Model.

\begin{tabular}{|l|c|c|c|}
\hline Component & $\begin{array}{c}\text { Before } \\
\text { treatment }\end{array}$ & $\begin{array}{c}\text { After } \\
\text { Treatment }\end{array}$ & Gain \\
\hline Sample & 35 & 35 & 35 \\
\hline $\begin{array}{l}\text { Minimum } \\
\text { score }\end{array}$ & 18,18 & 24,24 & 0,00 \\
\hline $\begin{array}{l}\text { Maximum } \\
\text { score }\end{array}$ & 57,58 & 63,64 & 0,46 \\
\hline Average & 33,33 & 51,52 & 0,26 \\
\hline $\begin{array}{l}\text { Deviation } \\
\text { standard }\end{array}$ & 9,44 & 7,85 & 0,13 \\
\hline Varians & 89,13 & 61,58 & 0,02 \\
\hline
\end{tabular}

The minimum score of critical thinking understanding before applying Conventional Instructional model was 18.18 , and after learning 24.24 with a gain score of 0.00 . The maximum score before learning is 57.58 and after learning 63.64 with a gain of 0.46 . In addition, the average score before taught by use conventional is 33.33 and after learning 51.26 with a gain of 0.26 , while the standard deviation before learning is 9.44 and after learning 7.85 with a gain of 0.13 . This shows that in general the understanding of critical thinking after being taught with conventional learning experiences differences compared to before learning.

\subsection{Testing Requirements Analysis}

\subsubsection{Normality Test}

To test the data normality, the researcher used the Kolmogorov-Smirnov test. The level of decision making if dcount $<\mathrm{D}_{\text {table }}$ at $=0.05$ or probability Dcount Dtable then the data used in the study is normally distributed. On the other hand, if the score of Dcount Dtable is at $=0.05$ or the probability of Dcount < Dtable, then the data used in the study is not normally distributed. The results of the 
normality test of research data on environment-based learning are presented in the following table

Table 1.4 The Results of the Normality Test of Gain Data on the Environment-Based Instructional Model Using the Kolmogorov-Smirnov Test.

\begin{tabular}{|c|l|c|c|c|c|}
\hline \multirow{2}{*}{ No } & \multicolumn{2}{|c|}{ Aspect } & \multicolumn{4}{|c|}{ Significany } \\
\cline { 3 - 6 } & & $\mathrm{N}$ & Pretes & Posttes & Alpha \\
\hline 1 & $\begin{array}{l}\text { Critical } \\
\text { thinking skill }\end{array}$ & 35 & 0,223 & 0,640 & 0,05 \\
\hline
\end{tabular}

Based on the table 1.4 above, the probability score before learning is 0.223, and after learning is 0.640. Because these scores are greater than alpha 0.05, the data used in this study was normally distributed. Furthermore, the results of the normality test of conventional data are presented in the following table.

Table 1.5 Normality Test on Convensional Model by Use Kolmogorov-Smirnov.

\begin{tabular}{|c|l|c|c|c|c|}
\hline \multirow{2}{*}{ No } & \multirow{2}{*}{ Aspect } & \multicolumn{4}{|c|}{ Signicancy } \\
\cline { 3 - 6 } & & $\mathrm{N}$ & Pretes & Posttes & Alpha \\
\hline 1 & $\begin{array}{l}\text { Critical } \\
\text { thinking skill }\end{array}$ & 35 & 0,419 & 0,819 & 0,05 \\
\hline
\end{tabular}

The homogeneity of the data was tested using Levene's test. The decision-making criteria if the score of F-count higher F-table or probability 0.05 then the research data is homogeneous. Contrastly, if the score of F-count $>$ Ftable or prob. $<0.05$ then the data was not homogeneous. The results of the data homogeneity test were presented in the following table

Table 1.6 Results of Data Homogeneity Test Using Levene test

\begin{tabular}{|c|c|c|c|c|}
\hline Aspect & F & df1 & df2 & Sig. \\
\hline Critical thinking skill & 1,295 & 3 & 136 & 0,077 \\
\hline
\end{tabular}

Based on the table above, the probability score for the critical thinking understanding is 0.077 . The score Fcount is greater than alpha 0.05 . It can be described that the data used in this study was homogeneous.

\subsection{Hypothesis Test}

Hypothesis of this research was to find out whether there was a difference understanding of critical thinking skill before and after being taught by Environment-Based compared to conventional model as presented in the following table.

Table 1.6 describes the t-count score of the difference before and after taught by environmental-based instructional model compared to conventional model on critical thinking skill 8.742. It Increases of critical thinking skill on Biodiversity material, after being taught with Environment-based nstructional model compared to Conventional model.

Table 1.7 Differences Of Students' Critical Thinking Skills Before And After Applying Environment-Based Biology Instruction and Convensional Models.

\begin{tabular}{|c|c|c|c|c|c|c|}
\hline $\begin{array}{c}\text { No } \\
\cdot\end{array}$ & Aspect & t hit. & $\begin{array}{c}\mathrm{t} \\
\text { tabe } \\
1\end{array}$ & $\begin{array}{c}\text { Prob } \\
\cdot\end{array}$ & $\begin{array}{c}\text { Alph } \\
\mathrm{a}\end{array}$ & $\begin{array}{c}\text { Conclusio } \\
\mathrm{n}\end{array}$ \\
\hline 1 & $\begin{array}{l}\text { Critical } \\
\text { thinkin } \\
\text { g skill }\end{array}$ & $\begin{array}{c}8,74 \\
2\end{array}$ & 1,68 & $\begin{array}{c}0,00 \\
0\end{array}$ & 0,05 & $\mathrm{H}_{0}$ ditolak \\
\hline
\end{tabular}

Based on the results of t-test, it shows that there are differences on students' critical thinking skill after being taught with Environment-based Instructional model compared to conventional learning.

\subsubsection{Effectiveness of Environment-Based Instructional Model and Convensional Model.}

The size and category of effectiveness of both Environment Based and Conventional models can be shown in the following table;

Table 1.8 The Effectiveness of Environment-Based Instructional Model and Conventional Models.

\begin{tabular}{|c|l|c|c|}
\hline No & \multicolumn{1}{|c|}{ Classes } & $\begin{array}{c}\text { N- } \\
\text { Gain }\end{array}$ & Category \\
\hline 1 & $\begin{array}{l}\text { Environmental- } \\
\text { Based }\end{array}$ & 0,57 & Medium \\
\hline 2 & Conventional & 0,26 & Low \\
\hline
\end{tabular}

Based on the following table 1.8 can be depicted that score N-Gain for Environment-based is higher 0.31 which is included in Medium Category. This result shows that Environmental Based is better than Conventional on Biodiversity material.

Environment - Based as a model instruction to students can improve their understanding of critical thinking. It is a instruction that emphasizes field practice, allows students' independence. The involvement of these students can stimulate the thinking process after going through observing and analyzing activities. The questions and assumptions put forward by students before learning will be answered after seeing the reality of the object under investigation.

It is related to Purwaningsih \& Wangid,(2019) states that the development of critical thinking skills can be done by utilizing learning media. Environment is one properly media in learning Biologi to improve critical thinking[23]. By applying an environment-based Instruction model, the students dominated the learning process or student-centered. It is related to Saiful amin et, al research (2020) on title "Effect of problem-based learning on critical thinking skills and environmental attitude" it showed that there were significant influence 
Problem Based Learning on students' critical thinking and Environment attitude. The students tend to respond directly about learning process when they meet real world [27].

Students are allowed to be actively involved in learning; mentally, intellectually, and socially emotionally. They assumed that can be able to optimally develop their cognitive, affective, and psychomotor aspects in a balanced, through the process of investigation or discovery. Learning activities involved maximally for all students to search and investigate systematically, critically, logically, and analytically. There is an increasing difference between the environment-based instructionl model than the conventional learning model on students' critical thinking. It is related to the results of M. Djajadi and A. Rauf (2020)," the using of outdoor or environment can increase students' achievement, moreover, the students tend to be sincere, active and had readiness in learning process [28].

The difference in the average gain score is higher the use of environment based model occured because each individual has different characteristics. Each individual had different ways of approaching the learning situation, in the way they receive, organize, respond, process information, and organize it based on the experiences they have met. It was related to research conducted by Tiara et al (2020), there is positive respond the use of environment as media on learning science [29]. From environment based model, the students can applied all the critical thing step, as stated Innis (2015), changwong, Sukkamart, Sisan (2018) "Critical thinking involves several steps, most of which adults breeze though without much thought [22]. These steps include identify the issue, think about the goal, brainstorm possible solutions, think through possible results, try one of the solutions, and finally, evaluate the outcome"

The findings above indicate that understanding critical thinking as an important variable in increasing students' knowledge capacity needs to be carried out in a learning atmosphere particularly the use of environmentbased mode. It provides direct interaction between students and learning objects. The existence of such an interaction stimulates students to raise questions about the object being observed, make assumptions, interpretations, and points of view according to their schema. The scheme is elaborated with group friends or teachers so that it gives birth to a comprehensive concept or understanding of the object of observation.

\section{CONCLUSION}

From the result, it can be concluded that; (1) there is a significant difference among students' critical thinking before to after being taught by the Environment-based instructional model and the Conventional model (2)
There is the effectiveness of using the environment-based instructional model on students' critical thinking skills.

\section{AUTHORS' CONTRIBUTIONS}

The author would like describe about the authors contributions. The first author arranged and conducted the research completely. Write down the scripts and analyzed the data into describe and inferensial statistic. Lastly, the first author presented it. The second author guided the first author to determine the research desaign and method that already arranged effectively. The third author guided and gave feedback related to the all the scenario of this research.

\section{ACKNOWLEDGMENTS}

In the secton, the authors thank to all the people who helped us in completing this paper. Your supports had huge contributions. Firstly, the authors thanks to the head of curriculum doctoral program Education University Indonesia who agreed to conduct the research. Secondly, the second author and third authord invested the time guiding and supporting to do the research. Thirdly, all the teachers and students of senior high school of Nort Konawe Regency who took part in this research. Lastly, all my family members particularly my children and my lovely wife that accompanied, supported and prayed in every single minute for completing my paper. The special thanks to my classmates whom the writer could not all your name in narrow space. You gave me much inspiration and input in writing the paper.

\section{REFERENCES}

[1] Liliasari, Scientific Concepts and Generic Skills Relationship. Bandung: International Seminar of Science Education, 2007.

[2] F. L. Badriyah, H. Mubarok, and B. K. Prahani, 'Profile of Students' Critical Thinking Skills and the Implementation of PBLRQA based on Blended Learning in Senior High School," Prism. Sains J. Pengkaj. Ilmu dan Pembelajaran Mat. dan IPA IKIP Mataram, vol. 9, no. 1, p. 38, 2021, doi: 10.33394/j-ps.v9i1.3911.

[3] E. Susetyarini and A. Fauzi, "Trend of critical thinking skill researches in biology education journals across Indonesia: From research design to data analysis," Int. J. Instr., vol. 13, no. 1, pp. 535550, 2020, doi: 10.29333/iji.2020.13135a.

[4] R. M. Sari, Sumarmi, I. K. Astina, D. H. Utomo, and Ridhwan, "Increasing Students Critical Thinking Skills and Learning Motivation Using Inquiry Mind Map," Int. J. Emerg. Technol. Learn., vol. 16, no. 3, pp. 4-19, 2021, doi: 10.3991/ijet.v16i03.16515.

[5] S. Sugiyarti, N. Fitriani, and R. Vebrian, 
"Penulisan Artikel Ilmiah Untuk Guru Sekolah Dasar Se-Kabupaten Bangka," J. Pengabdi. UntukMu NegeRI, vol. 3, no. 1, pp. 1-5, 2019, doi: 10.37859/jpumri.v3i1.1294.

[6] Jahidin, Pembelajaran Biologi: Perspektif Pembelajaran Abad 21. Kendari: CV Metro Graphia, 2021.

[7] M. Supriatna, "Pembalajaran IPA untuk Mahasiswa Program Calon Guru SD dengan Menggunakan Pendekatan Lingkungan yang Berorientasi kepada Pengembangan Kecerdasan Intelektual dan Emosional." Tesis pada PPs UPI Bandung tidak diterbitkan, 2003.

[8] Lailah fauziah, F. Rizkiyah, M. Miarsyah, and R. Hendi Ristanto, "Pengembangan Ttct-V (Torrance Test of Creative Thinking Verbal) Berbasis Lingkungan Untuk Tingkat Sma," Bio-Lectura, vol. 8, no. 1, pp. 1-11, 2021, doi: 10.31849/bl.v8i1.4534.

[9] M. Muhlisin, I. Rosiana, Y. Rahayuningsih, and Y. Suharyana, "The Efforts to Improve Environmental Behavior and Critical Thinking of Students through Guided Inquiry-Based Learning on Environmental Education-Based Science," $J$. Penelit. dan Pembelajaran IPA, vol. 5, no. 2, p. 202, 2019, doi: 10.30870/jppi.v5i2.4861.

[10] N. M. Seel, T. Lehmann, P. Blumschein, and O. A. Podolskiy, Instructional design for learning: Theoritical foundations. Netherlands: Sense Publisher, 2017.

[11] R. E. Slavin, Educational Psychology Theory and Practice; Theory and Practice. United States of America: Pearson Education, Inc, 2006.

[12] N. Corder, Learning to teach Adult and an Introduction. New York: Routledge, 2010.

[13] Prayitno, Dasar Teori dan Praksis Pendidikan. Jakarta: Grasindo, 2007.

[14] W. Sanjaya, Kurikulum dan Pembelajaran. Jakarta: Kencana Prenada Media Group, 2011.

[15] Rusman, Belajar dan Pembelajaran Berorientasi Standar Proses Pendidikan. Jakarta: Kencana, 2017.

[16] B. R. Joyce, M. Weil, and E. Calhoun, Models of teaching. United States of America: Pearson Education, 2015.

[17] L. M. Syarif and A. G. Wibisina, Hukum Lingkungan Teori, Legislasi dan Studi Kasus. Jakarta: American people through the United States Agency for International Development (USAID), 2012.

[18] J. Ernst and M. Monroe, "The effects of environment-based education on students' critical thinking skills and disposition toward critical thinking," Environ. Educ. Res., vol. 10, no. 4, 2004, doi: 10.1080/1350462042000291038.

[19] G. a. Lieberman and L. L. Hoody, "Closing the achievement gap. Using the environment as an integrate context for learning," State Educ. Environ. Roundtable, 1998.

[20] J. L. Bucholz and J. L. Sheffler, "Creating a Warm and Inclusive Classroom Environment: Planning for All Children to Feel Welcome," Electron. J. Incl. Educ., vol. 2, no. 4, 2009.

[21] J. Butterworth and G. Thwaites, Thinking Skills: Critical Thinking and problemsolving Second Edition. New York: Cambridge University Press, 2013.

[22] K. Changwong, A. Sukkamart, and B. Sisan, "Critical thinking skill development: Analysis of a new learning management model for Thai high schools," J. Int. Stud., vol. 11, no. 2, pp. 37-48, 2018, doi: 10.14254/2071-8330.2018/11-2/3.

[23] W. Purwaningsih and M. N. Wangid, "Improving students' critical thinking skills using Time Bar Media in Mathemathics learning in the third grade primary school," J. Prima Edukasia, vol. 9, no. 2, pp. 248-260, 2021, doi: 10.21831/jpe.v9i2.39429.

[24] P. Johnson, "Growing physical, social and cognitive capacity: Engaging with natural environments," Int. Educ. J., vol. 8, no. 2, 2007.

[25] Liliasari, "Pengembangan Berpikir Kritis Sebagai Karakter Bangsa Indonesia Melalui Pendidikan Sains Berbasis ICT. Potret Profesionalisme Guru dalam membangun Karakter Bangsa," 2011, pp. 456-466.

[26] E. S. et. a. Inch, Critical Thinking \& Communication, the Use of Reason in Argument. United States of America: Pearson Education.

[27] N. Fadilla, L. Nurlaela, T. Rijanto, S. R. Ariyanto, L. Rahmah, and S. Huda, "Effect of problem-based learning on critical thinking skills," J. Phys. Conf. Ser., vol. 1810, no. 1, pp. 743-755, 2021, doi: 10.1088/1742-6596/1810/1/012060.

[28] M. Djajadi and A. Rauf, "Learning physics of motion and force using the outdoor activities: An effort to increase students' interest and achievement at secondary school," J. Pendidik IPA Indones., vol. 9, no. 2, pp. 208-218, 2020, doi: 10.15294/jpii.v9i2.24001

[29] Tiara et al., "Utilization of environment as a learning media or natural science study in junior high schools," Int. J. Sci. Technol. Res., vol. 9, no. 2, pp. 1981-1983, 2020. 